\section{Ascorbic Acid Oxidase Activity in Apple Buds: Relation to Thidiazuron- induced Lateral Budbreak}

\author{
Shiow Y. Wang and Miklos Faust \\ Fruit Laboratory, Agricultural Research Service, U.S. Department of \\ Agriculture, Beltsville, MD 20705
}

Additional index words. paradormancy, correlative inhibitor, diethyldithiocarbamate, 8hydroxyquinoline, sodium azide, Malus domestica

\begin{abstract}
The activity of ascorbic acid oxidase (AAO) was studied in apple (Malus domestica Borkh.) buds during dormancy and thidiazuron-induced budbreak. In dormant buds, activity of AAO was low compared with buds that were treated with thidiazuron and had resumed growth. An increase in AAO activity began at the time of metabolic transition from dormancy to budbreak. The highest level of activity was reached 10 days after thidiazuron induction during the expansion growth phase. In vitro AAO activity of apple bud extract was increased by addition of $\mathrm{Cu}\left(\mathrm{CuSO}_{4}\right)$ and inhibited by $\mathrm{Cu}$-chelating agents, diethyldithiocarbamate (DDC), sodium azide $\left(\mathrm{NaN}_{3}\right)$, and 8-hydroxyquinoiine (8-OH-Q). In vivo treatment of apple buds with $\mathrm{Cu}$-chelating agents inhibited AAO activity and bud growth but not budbreak. Chemical name used: $N$ - phenyl $-N^{\prime}-1,2,3$-thidiazol-5-ylurea

(thidiazuron).
\end{abstract}

Many studies have demonstrated the marked physiological changes associated with differentiation and subsequent growth of plant cells. Ascorbic acid oxidase (AAO; EC 1.10.3.3.) is a $\mathrm{Cu}$-containing enzyme that catalyzes the oxidation of ascorbate to 2-dehydroascorbate with the concomitant reduction of molecular oxygen to water (Ohkawa et al., 1989). Plants use ascorbate as an antioxidant in an ascorbate peroxidase (EC 1.11.1.11) reaction that produces dehydroascorbate. Ascorbate is then regenerated in a reduced glutathione (GSH)-dependent reaction catalyzed by dehydroascorbate reductase (EC 1.8.5.1). The oxidized disulfide

Received for publication 20 Dec. 1991. Accepted for publication 23 Apr. 1992. The cost of publishing this paper was defrayed in part by the payment of page charges. Under postal regulations, this paper therefore must be hereby marked $a d$ vertisement solely to indicate this fact. form of glutathione (GSSG) is then reduced back to GSH in a reaction involving glutathione reductase (EC 1.6.4.2) and NADPH (Dalton et al., 1986). Fuchigami and Nee (1987) speculated that glutathione is involved in overcoming rest in temperate woody perennials. We previously reported an increase in ascorbic acid, GSH, total glutathione, total nonprotein thiol, and nonglutathione thiol after thidiazuron-induced budbreak (Wang et al., 1991a). Thidiazuron-induced budbreak also increased the ratio of GSH : GSSG and activities of ascorbate free radical reductase (EC 1.6.5.4), ascorbate peroxidase, dehydroascorbate reductase, glutathione reductase, and superoxide dismutase (EC 1.15.1.1) (Wang et al., 1991a, 1991b). These data suggest that the termination of dormancy and induction of budbreak may require the scavenging of superoxide anions and peroxide in bud tissue (Wang et al., 1991a, 1991b). AAO has been reported in several higher plants (Newcomb, 1951), but its function in the metabolism of the plant cell is unclear. Newcomb (1951) and Morre et al. (1987) suggested that the AAO system might serve to generate energy-rich phosphates or alter properties of the plasma membrane. High activity of AAO is characteristic of diverse, actively growing tissue (Newcomb, 1951). High AAO activity apparently is associated with rapid growth of the primary wall (Honda, 1955; Newcomb, 1951; Waygood, 1950). We conducted our study to determine the changes in the activity of AAO in apple buds and to better understand the involvement of AAO in apple buds during budbreak and resumption of growth.

The growing conditions of 'York Imperial' apple seedlings and treatment methodology used in this study were described by Wang et al. (1986). The seedlings were planted in 3.5-liter pots and grown in a greenhouse with no chilling. Radiation sources

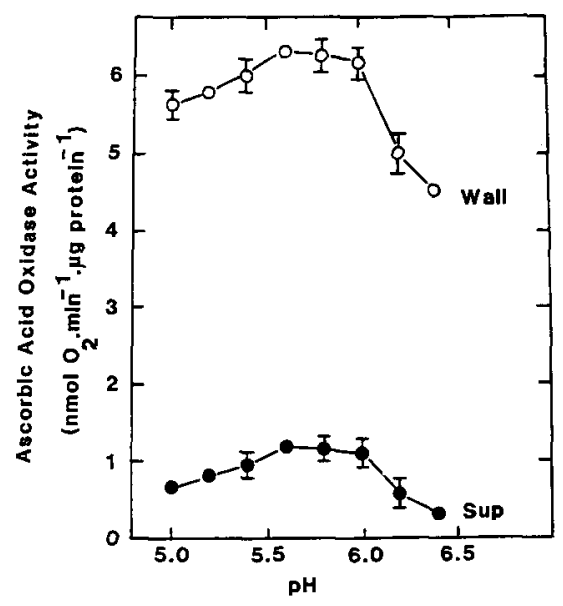

Fig. 1. Effect of $\mathrm{pH}$ on ascorbic acid oxidase activity (AAO) in apple buds; AAO was extracted from apple buds 10 days after treatment with $100 \mu \mathrm{M}$ thidiazuron. Wall $=$ cell wall fraction. Sup $=$ supernatant fraction. Data are the means of three replicate samples. Vertical bars denote \pm SE, bars smaller than the symbols are not shown (Expt. 1). 


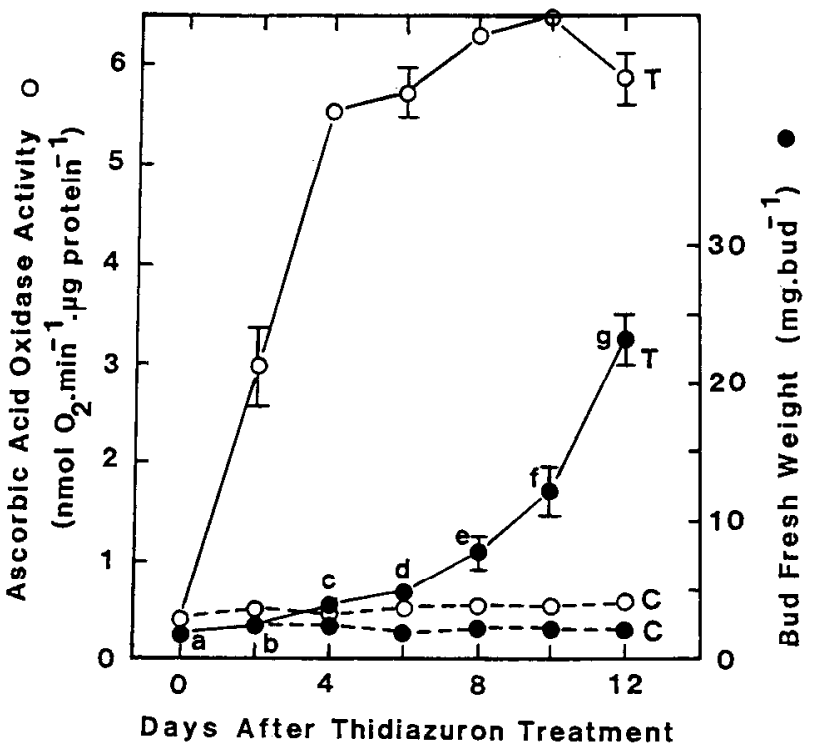

Fig. 2. Changes of ascorbic acid oxidase activity and fresh bud weight associated with dormancy, thidiazuron-induced (T) budbreak, and growth resumption in apple buds compared with untreated buds (C). Stages of bud development were classified as follows: a, dormant bud; b, first swell; c, full swell; d, side green; e, green tip; f, bud expansion; g, bud open. Data are the means of three replicate samples. Vertical bars denote $\pm \mathrm{SE}$, bars smaller than the symbols are not shown (Expt. 2).

Table 1. The effects of the Cu-chelating agents diethyldithiocarbamate (DDC), sodium azide $\left(\mathrm{NaN}_{3}\right)$, and 8-hydroxyquinoline (8-OH-Q), on bud growth and ascorbic acid oxidase (AAO) activity in apple buds (Expt. 2).,.,

\begin{tabular}{lccc}
\hline & $\begin{array}{c}\text { Inhibitor } \\
\text { concn (mM) }\end{array}$ & $\begin{array}{c}\text { Fresh wt } \\
\text { (mg/bud) }\end{array}$ & $\begin{array}{c}\text { AAO activity } \\
\text { (nmol } \mathrm{O}_{2} / \mathrm{min} \text { per } \\
\mu \mathrm{g} \text { protein) }\end{array}$ \\
\hline Control & 0.0 & $13.2 \pm 1.4$ & $6.57 \pm 0.21$ \\
$\mathrm{DDC}$ & 0.1 & $9.2 \pm 1.0$ & $5.56 \pm 0.18$ \\
& 0.5 & $6.3 \pm 0.7$ & $4.33 \pm 0.11$ \\
$\mathrm{NaN}_{3}$ & 1.0 & $4.2 \pm 0.5$ & $3.96 \pm 0.07$ \\
& 0.1 & $11.6 \pm 1.1$ & $6.09 \pm 0.20$ \\
$8-\mathrm{OH}-\mathrm{Q}$ & 0.5 & $7.9 \pm 0.9$ & $5.05 \pm 0.10$ \\
& 1.0 & $6.1 \pm 0.8$ & $4.64 \pm 0.09$ \\
& 0.1 & $12.0 \pm 1.2$ & $6.31 \pm 0.17$ \\
& 0.5 & $10.6 \pm 1.1$ & $5.70 \pm 0.16$ \\
& 1.0 & $8.2 \pm 0.8$ & $5.19 \pm 0.12$ \\
\hline
\end{tabular}

${ }^{2}$ Buds were treated with indicated concentrations of the chelating agents followed by $100 \mu \mathrm{M}$ of thidiazuron $4 \mathrm{~h}$ later. Samples were measured after 10 days. AAO activity was assayed with the cell wall fraction at $\mathrm{pH} 5.6$.

${ }^{\mathrm{Y}}$ Mean of the three replicates $\pm \mathrm{SE}$.

in the greenhouse consisted of natural daylight and 400-W high-pressure sodium lamps (Energy Technics, York, Pa.); which provided a photosynthetically active radiation level of $\approx 400$ to $500 \mu \mathrm{mol} \cdot \mathrm{m}^{-2} \cdot \mathrm{s}^{-1}$ for 12 h. day $^{-1}(0700$ to $1900 \mathrm{HR})$. Temperatures were $\approx 25 / 20 \mathrm{C}$ day/night, and relative humidity was $65 \%$. Plants were $\approx 1 \mathrm{~m}$ high with a single stem. The buds were in paradormancy, and removal of apical dominance could have induced lateral budbreak. A completely randomized design was used for each of the four experiments. Thidiazuron (100 $\mu \mathrm{M})$ and selected concentrations $(0.1,0.5$, or $1.0 \mathrm{~mm}$ ) of the $\mathrm{Cu}$-chelating agents diethyldithiocarbamate (DDC), sodium azide $\left(\mathrm{NaN}_{3}\right)$, or 8-hydroxyquinoline (8-OH-Q) were prepared in $2.5 \%(\mathrm{v} / \mathrm{v})$ dimethyl sulfoxide (DMSO) plus $0.5 \%$ (v/v) Tween 20 and applied to the buds with a brush until runoff. Control plants were treated with only DMSO and Tween 20. Only the upper seven buds were treated. Lateral buds were used, and buds were analyzed as a whole for AAO activity and ascorbate content.

Ascorbic acid oxidase activity and $p H$ (Expt. 1). To determine the effect of $\mathrm{pH}$ on AAO activity in apple buds, each of 75 apple seedlings was treated with $100 \mu \mathrm{M}$ thidiazuron. AAO was extracted from apple buds 10 days after treatment. Triplicate bud samples of $0.2 \mathrm{~g}$ fresh weight were collected for each of eight $\mathrm{pH}$ values tested (range 5.0-6.4). Excised bud tissue $(200 \mathrm{mg}$ ) was immediately ground in a cool mortar and pestle with $400 \mu 1100 \mu$ m leupeptin (Sigma, St. Louis). The homogenate was mixed with $1600 \mu \mathrm{l}$ $0.1 \mathrm{M}$ sodium citrate buffer, $\mathrm{pH} 5.6$, and centrifuged at $800 \times g$ for $20 \mathrm{~min}$ at $0 \mathrm{C}$ to obtain a clear supernatant. The ionic strength of the buffer was high enough to elute AAO activity from the wall residue (Lin and Varner, 1991). This supernatant fraction was designated as wall fraction and used for assaying AAO activity. The supernatant was further centrifuged for $30 \mathrm{~min}$ at $20,000 \times$ $g$. This supernatant fraction (SUP) was also used to assay AAO activity and to compare its activity with wall fraction. AAO was determined using an oxygen electrode (YSI model 53, YSI Inc., Yellow Springs, Ohio) by measuring $\mathrm{O}_{2}$ consumption at $28 \mathrm{C}$. The reaction mixture contained $1.5 \mathrm{ml}$ of $0.1 \mathrm{M}$ sodium citrate buffer adjusted with $1 \mathrm{M} \mathrm{HCl}$ or $\mathrm{NaOH}$ to the desired $\mathrm{pH}$ value, $0.3 \mathrm{ml}$ of $10 \mathrm{~mm} \mathrm{Na}$ ascorbate, $1.15 \mathrm{ml} \mathrm{ddH}_{2} \mathrm{O}$, and $50 \mu 1$ of crude enzyme extract. Enzyme activity was expressed as nanomoles of $\mathrm{O}_{2}$ consumed per minute per microgram protein basis. Protein content was determined according to Bradford (1976), using bovine serum albumin as a standard.

Copper-chelating agents, bud growth, and $A A O$ activity (Expt. 2). The effect of the $\mathrm{Cu}$ chelating agents DDC, $\mathrm{NaN}_{3}$, and 8-OH-Q $(0.1,0.5$, or $1.0 \mathrm{~mm})$ on bud growth and AAO activity was studied in vivo. Thirty plants were used for each concentration of $\mathrm{Cu}$-chelating agent. Their application was followed by $100 \mu \mathrm{M}$ of thidiazuron $4 \mathrm{~h}$ later. Bud growth and AAO activity were measured after 10 days. Enzyme activity in the cell wall fraction was assayed at $\mathrm{pH}$ 5.6.

Copper-chelating agents and $A A O$ activity in vitro (Expt. 3). The effect of $\mathrm{Cu}$, DDC, $\mathrm{NaN}_{3}$, and 8-OH-Q on the activity of AAO oxidase was studied in vitro. Seventy-five plants were treated with $100 \mu \mathrm{M}$ thidiazuron. AAO was extracted from apple buds 10 days after they had been treated with thidiazuron. The test compounds, at various concentrations, were preincubated with crude cell wall AAO extract at $\mathrm{pH} 5.6$ for $3 \mathrm{~min}$ before the $\mathrm{Na}$ ascorbate substrate was added. The measurement of enzyme activity was conducted as described in Expt. 1.

$A A O$ activity, ascorbate, and bud characteristics (Expt. 4). To study the changes of AAO activity, ascorbate content and fresh bud weight associated with dormancy, thidiazuron-induced budbreak, and growth resumption in apple buds, 1050 apple seedlings were used. One-third of the plants were used as control and two-thirds were treated with thidiazuron. Buds from control and thidiazuron-treated plants were sampled at day 0 and then at 2-day intervals over 12 days. Triplicate bud samples of $0.2 \mathrm{~g}$ fresh weight were collected at each sampling time. Depending on their size, the number of buds required ranged from $\approx 10$ to 125 . AAO activity was assayed as described in Expt. 1.

Ascorbate was determined using the method of Arakawa et al. (1981) and Nakagawara and Sagisaka (1984). This assay is based on the reduction of ferric ion to ferrous ion by the ascorbic acid solution followed by formation of a red chelate between ferrous ion and 4,7-diphenyl-1,10-phenanthrolin (bathophenanthroline) that absorbs at $534 \mathrm{~nm}$. Bud tissue $(200 \mathrm{mg}$ ) was homogenized in $2 \mathrm{ml}$ of cold $5 \%(\mathrm{w} / \mathrm{v})$ trichloroacetic acid containing $80 \mathrm{mg}$ polyclar AT (polyvinylpolypyrrolidone; Sigma) and $400 \mathrm{mg}$ sea sand. The homogenate was filtered through four layers of Miracloth and centrifuged at $16,000 \times g$ for $10 \mathrm{~min}$ at $4 \mathrm{C}$. The supernatant was used for the ascorbate assay. The ascorbate assay 


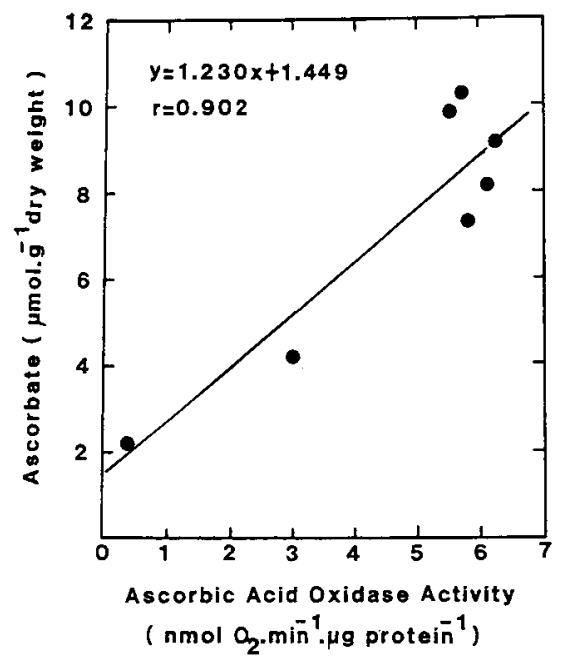

Fig. 3. Relation of ascorbate content (micromoles ascorbate per gram dry weight) to ascorbic acid oxidase activity (nanomoles $\mathrm{O}_{2}$ per minute per microgram protein) in apple buds (Expt. 4).

Table 2. The effects of $\mathrm{Cu}\left(\mathrm{CuSO}_{4}\right)$ and the $\mathrm{Cu}$ chelating agents diethyldithiocarbamate (DDC), sodium azide $\left(\mathrm{NaN}_{3}\right)$, and 8-hydroxyquinoline (8-OH-Q), on relative ascorbic acid oxidase (AAO) activity in apple bud extract (Expt. 3). ${ }^{2 . y}$

\begin{tabular}{lcc}
\hline \hline Treatment & $\begin{array}{c}\text { Inhibitor } \\
\text { concn }(\mu \mathrm{M})\end{array}$ & $\begin{array}{c}\text { AAO activity } \\
(\% \text { of control) }\end{array}$ \\
\hline $\mathrm{CuSO}_{4}$ & 0.05 & $513 \pm 9.8$ \\
& 0.1 & $795 \pm 11.9$ \\
$\mathrm{DDC}$ & 1 & $994 \pm 14.3$ \\
& 10 & $84.9 \pm 7.3$ \\
& 25 & $58.4 \pm 4.7$ \\
$\mathrm{NaN}_{3}$ & 50 & $16.0 \pm 2.4$ \\
& 50 & $57.8 \pm 3.9$ \\
$8-\mathrm{OH}-\mathrm{Q}$ & 100 & $19.4 \pm 2.5$ \\
& 50 & $78.8 \pm 6.1$ \\
& 100 & $62.6 \pm 4.7$
\end{tabular}

${ }^{2}$ Ascorbic acid oxidase was extracted from apple buds 10 days after treatment with $100 \mu \mathrm{M}$ thidiazuron. The experiments were conducted with the cell wall fraction at $\mathrm{pH}$ 5.6. Absolute value for AAO activity in the control was $6.50 \mathrm{nmol} \mathrm{O}_{2} /$ $\min$ per $\mu \mathrm{g}$ protein.

${ }^{\mathrm{Y}}$ Mean of three replicates $\pm \mathrm{SE}$.

mixture contained $0.1 \mathrm{ml}$ of the sample extract, $0.5 \mathrm{ml}$ of absolute ethanol, $0.6 \mathrm{M}$ trichloroacetic acid, $3 \mathrm{~mm}$ bathophenanthroline, $8 \mathrm{mM} \mathrm{H}_{3} \mathrm{PO}_{4}$, and $0.17 \mathrm{~mm} \mathrm{FeCl}_{3}$. The final total volume was $1.5 \mathrm{ml}$. The solution was kept at $30 \mathrm{C}$ for $90 \mathrm{~min}$ to allow the $\mathrm{Fe}^{2+}$ bathophenanthroline complex to develop. The absorbance of the colored solution was measured at $534 \mathrm{~nm}$, using a spectrophotometer (Shimadzu UV-160A, Columbia, Md.). A standard curve in the range $0-10 \mu \mathrm{mol}$ ascorbate was used to calculate ascorbate content in apple buds.

Thidiazuron stimulated budbreak; 2 days after its application, the treated buds began to swell. As previously reported, untreated buds from the same plant and buds from control plants did not swell (Wang et al., 1991a), indicating that thidiazuron was not translocated in apple stems.

The enzyme extract of apple bud tissue from the cell wall fraction contained higher levels of enzymatic activity than the supernatant fraction (Fig. 1), which supports reports that AAO is structurally associated with cell walls (Hansl, 1955; Honda, 1955; Newcomb, 1951; Waygood, 1950). The optimal $\mathrm{pH}$ for the enzymatic oxidation of ascorbic acid by the cell wall or supernatant fraction of apple bud tissue was within the $\mathrm{pH}$ range of 5.5 and 6.0 (Fig. 1), with a rather sharp decline in activity above $\mathrm{pH}$ 6.0. This pattern agrees with the $\mathrm{pH}$ optimum for AAO reported by others (Dawson and Magee, 1955; Mertz, 1961). All subsequent experiments were conducted with the cell wall fraction at $\mathrm{pH}$ 5.6.

Copper-chelating agents DDC, $\mathrm{NaN}_{3}$, and 8-OH-Q did not affect thidiazuron-induced budbreak (data not shown) but evidently inhibited bud growth and AAO activity (Table 1). The degree of inhibition increased with increased inhibitor concentration. The decrease of AAO activity was probably due to the inhibition of bud growth by DDC, $\mathrm{NaN}_{3}$, and $8-\mathrm{OH}-\mathrm{Q}$. It seems unlikely that $\mathrm{AAO}$ was involved in scavenging activity during budbreak, because the oxidation of ascorbate to 2-dehydroascorbate by AAO consumes molecular oxygen rather than hydrogen peroxide (Ohkawa et al., 1989). Very little is known about the specific functions of $\mathrm{Cu}$ in fruit trees (Faust, 1989). However, fruit trees respond to $\mathrm{Cu}$ deficiency with severe dieback, which is a more severe reaction than their response to other nutrient deficiencies.

AAO activity increased during budbreak, and growth resumed following thidiazuron application (Fig. 2). The control buds remained dormant and had low enzyme activity throughout the experiment. An increase in AAO activity began at the time of metabolic transition, when buds emerged from paradormancy induced by thidiazuron, and resumed growth. AAO activity increased rapidly after induction, and the highest level of activity was reached 10 days later, during the expansion growth phase (Fig. 2). AAO activity was correlated with the growth rate in bud tissue $(r=0.902)$; its activity declined by day 12 , probably due to a general increase in protein content. The association of AAO with the walls of cells undergoing rapid growth has been reported in root tips of various plants (Honda, 1955; Jensen and Kavaljian, 1956; Mertz, 1961; Reid, 1941) and in fruits and leaves of zucchini squash (Cucurbita pepo L.) (Lin and Vamer, 1991). AAO activity also increased rapidly during the growth of cultured pumpkin (Cucurbita sp.) and tobacco (Nicotiana tabacum L.) pith cells (Esaka et al., 1988, 1989; Newcomb, 1951).

The ascorbate content was positively related to AAO activity (Fig. 3). Since intracellular ascorbate localization was not determined in this study, we do not know the distribution of ascorbate within the cell. Ascorbic acid acts as an antioxidant and also functions as a co-substrate of plant peroxidases, such as the ascorbate peroxidase or oxidase system that produces dehydroascorbate (Halliwell, 1982). Increased ascorbic acid content in apple buds was associated with thidiazuron-induced budbreak (Wang et al., 1991a).

AAO activity in apple bud extract was markedly increased by $\mathrm{Cu}\left(\mathrm{CuSO}_{4}\right)$ and was inhibited by the $\mathrm{Cu}$-chelating agents in vitro (Table 2). The degree of increase or inhibition was related to the concentration of $\mathrm{Cu}$ or $\mathrm{Cu}$-chelating agents. Copper sulfate at 1 , 0.1 , and $0.05 \mu \mathrm{M}$ increased enzyme activity by 10,8 , and 5 times over the control, respectively. At $50 \mu \mathrm{M}, \mathrm{DDC}, \mathrm{NaN}_{3}$, and 8OH-Q inhibited AAO activity in apple bud extract by $84 \%, 42 \%$, and $21 \%$, respectively. At $100 \mu \mathrm{M}, \mathrm{NaN}_{3}$, and 8-OH-Q inhibited enzyme activity $80 \%$ and $37 \%$, respectively. These data suggest the participation of a $\mathrm{Cu}$ enzyme in the oxidation of ascorbic acid in apple buds. Esaka et al. (1989) showed a marked increase in AAO activity in pumpkin callus when $\mathrm{Cu}$ was added to the culture medium, and the amount of AAO protein in pumpkin callus was controlled by $\mathrm{Cu}$, a prosthetic metal of the enzyme (Esaka et al., 1988).

These studies indicate that AAO is largely localized in the cell walls of apple buds; it is unlikely to be involved in scavenging activity during budbreak because in vivo $\mathrm{Cu}-$ chelating agents showed no inhibiting effect on thidiazuron-induced budbreak. The changes in AAO activity that occur in thidiazuron-treated apple buds appear to be associated with the resumption of growth. The rapid increase in enzyme activity parallels rapid cell growth, suggesting that AAO might be involved in the reorganization of the cell wall in apple buds to allow for the buds' expansion. Whether the changes in enzyme activity in the thidiazuron-treated buds are similar to those during dormancy and bud growth under natural conditions warrants further study.

\section{Literature Cited}

Arakawa, N., K. Tsutsumi, N.G. Sanceda, T. Kurata, and C. Inagaki. 1981. A rapid and sensitive method for the determination of ascorbic acid using 4,7-diphenyl-1,10-phenanthroline. Agr. Biol. Chem. 45:1289-1290.

Bradford, M.M. 1976. A rapid and sensitive method for the quantitation of microgram quantities of protein utilizing the principle of protein-dye binding. Anal. Biochem. 72:248-254.

Dalton, D.A., F.J. Hanus, S.A. Russell, and H.J. Evans. 1986. Enzymatic reactions of ascorbate and glutathione that prevent peroxide damage in soybean root nodules. Proc. Natl. Acad. Sci. USA 83:3811-3815.

Dawson, C.R. and R.J. Magee. 1955. Ascorbic acid oxidase, p. 831-835. In: S.P. Colowick (ed.). Methods in enzymology, vol. II. Academic, New York.

Esaka, M., J. Imagi, K. Suzuki, and K. Kubota. 1988. Formation of ascorbate oxidase in cultured pumpkin cells. Plant Cell Physiol. 29:231235 .

Esaka, M., H. Fukui, K. Suzuki, and K. Kubota. 1989. Secretion of ascorbate oxidase by suspension-cultured pumpkin cells. Phytochemistry 28:117-119.

Faust, M. 1989. Physiology of temperate zone fruit trees. Wiley, New York.

Fuchigami, L.H. and C.C. Nee. 1987. Degree growth stage model and rest-breaking mecha- 
nisms in temperate woody perennials. HortScience 22:836-845.

Halliwell, B. 1982. Ascorbic acid and the illuminated chloroplast, p. 263-274. In: P.A. Seib and B.M. Tolbert (eds.). Ascorbic acid: Chemistry, metabolism and uses. Amer. Chem. Soc., Washington, D.C.

Hansl, N.R. 1955. Atmungsenzymsysteme von Avene in ihrer Beziehung zum Wachstum. Osterr. Akad. Wiss., Math. Naturw 64:25-47.

Honda, S.I. 1955. Ascorbic acid oxidase in barley roots. Plant Physiol. 30:174-181.

Jensen. W.A. and L.G. Kavaljian. 1956. The cytochemical localization of asorbic acid in root tip cells. J. Biophys. Biochem. Cytol. 2:87-92.

Lin, L.S. and J.E. Varner. 1991. Expression of ascorbic acid oxidase in zucchini squash $(\mathrm{Cu}$ curbtra pepo L.). Plant Physiol. 96:159-165.
Mertz, D. 1961. Distribution and cellular localization of ascorbic acid oxidase in the maize root tip. Amer. J. Bot. 48:405-413.

Morre, D.J., F.L. Crane, I.L. Sun, and P. Navas. 1987. The role of ascorbate in biomembrane energetics. Ann. N.Y. Acad. Sci. 498:153-171. Nakagawara, S. and S. Sagisaka. 1984. Increase in enzyme activities related to ascorbate metabolism during cold acclimation of poplar twigs. Plant Cell Physiol. 25:899-906.

Newcomb, E.H. 1951. Effect of auxin on ascorbic oxidase activity in tobacco pith cells. Proc. Soc. Expt. Biol. Med. 76:504-509.

Ohkawa, J., N. Okada, A. Shinmyo, and M. Takano. 1989. Primary structure of cucumber (Cucumis sativus) ascorbate oxidase deduced from cDNA sequence: Homology with blue copper proteins and tissue specific expression. Proc.
Natl Acad Sci USA 86:1239-1243.

Reid, M.E. 1941. Relation of vitamin C to cell size in growing regions of the primary root of cow pea seedlings. Amer. J. Bot. 28:41-415.

Wang,S.Y., H.J, Jiao, and M. Faust. 1991a. Changes in ascorbate, glutathione, and related enzyme activities during thidiazuron-induced bud break of apple. Physiol. Plant. 82:231-236.

Wang, S.Y., H.J. Jiao, and M. Faust. 1991b. Changes in superoxide dismutase activity during thidiazuron-induced budbreak of apple. HortScience 26:1202-1204.

Wang, S.Y., G.L. Steffens, and M. Faust. 1986. Breaking bud dormancy in apple with a plant bioregulator, thidiazuron. Phytochemistry 25:311-317.

Waygood, E.R. 1950. Respiratory enzymes in wheat. Can. J. Res. Sec. C. 28:7-62. 